\title{
Performance Evaluation of an Automated Microbiological Stainer, KS-S100
}

Sun Min Lee, Hyun-

Ji Lee, and Chulhun L. Chang

Department of Laboratory Medicine, Pusan National University Yangsan Hospital, Yangsan, Korea

Corresponding author: Chulhun L. Chang Department of Laboratory Medicine, Pusan National University Yangsan Hospital, 20 Geumo-ro, Mulgeum-eup, Yangsan 50612, Korea Tel: +82-55-360-1877 Fax: +82-55-360-1880 E-mail: cchl@pusan.ac.kr
Background: There have been few evaluations of the performance of automatic stainers used instead of manual staining in clinical laboratories. We evaluated the performance of an automated stainer, KS-S100 (KS Co. Ltd., Korea), in Gram and acid-fast fluorescence staining of clinical specimens.

Methods: Repeatability was evaluated by comparing the results of Gram stains performed 10 times over 5 days using two standard strains and duplicated acid-fast bacilli (AFB) fluorescence stains using 40 samples. Comparisons to manual staining and to another automatic stainer, AT-2000 (Dagatron, Korea), were performed using 40 remnant respiratory specimens or liquid AFB culture media. The results were interpreted by two experienced technicians, and total test time was measured during the staining of 1, 10, and 20 slides.

Results: All 10 pairs of Gram staining results obtained with KS-S100 were identical, and the concordance rate of the duplicate AFB fluorescence stains was 92.5\%. Among the results for 20 culture-positive liquid media samples, three AFB fluorescent staining results were not concordant. The weighted kappa values between KS-S100 and manual staining for Gram and AFB fluorescence staining were both 0.94 , with concordance within the \pm 1 -grade range. For the staining of a single slide, manual staining was faster. KS-S100 was more efficient than AT-2000 at staining 20 slides.

Conclusions: The automated stainer KS-S100 showed reproducible results comparable to those of manual staining in two major microbiological staining methods, Gram and AFB fluorescence staining, used in clinical applications. Performance evaluations should be conducted before implementation of the automated stainer in microbiological staining.

(J Lab Med Qual Assur 2017;39:162-167)

Key Words: Bacteria, Gram's stain, Mycobacterium, Automation, Bacteriology

Received June 1, 2017, Revision received September 22, 2017, Accepted October 10, 2017

\section{서론}

임상미생물학 검사에서 염색은 검체에서 감염원을 밝히기 위해 첫 번째로 시도되는 검사이며, 세균 동정의 각 단계에서 정확성을 보증하는 중요한 역할을 한다[1-4]. 감염증을 일으 키는 세균을 분류하는 첫 번째 기준이 되는 그람염색(Gram stain)은 비교적 검사가 간단하지만 숙련된 검사자가 아니라 면 염색상에 따라 잘못된 판독을 할 수 있다 $[1,2]$. 전염력 높은 결핵 환자의 객담에서 마이코박테리아(Mycobacteria)를 신속 하게 검출할 수 있는 항산균(acid-fast bacilli) 도말검사의 경 우 염색과 판독에 있어서 숙련된 검사실에서 수행되어야 한다
〔3,4]. 미생물 염색을 자동화 장비로 시행하는 경우 많은 양의 검체를 일정한 조건으로 염색을 수행할 수 있으며, 검사자가 시약과 검체에 노출되는 위험을 줄일 수 있다[5-7]. 이와 같은 이유로 많은 검사실에서 그람염색이나 항산균 염색을 자동염 색기로 시행하고 있지만 해당 장비의 성능에 대하여 수기염색 과 객관적으로 평가한 결과 보고는 많지 않다[5-8].

이에 본 연구자는 국내에서 개발된 자동염색기인 KS-S100 (KS Co. Ltd., Naju, Korea)에 대하여 임상 미생물검사실에 서 수기염색이나 기존 장비를 대신하여 사용하기에 적절한 성 능을 보이며 사용하기 편의성이 있는지를 평가하고자 하였다. 


\section{Journal of LABORATORY MEDICINE and QUALITY ASSURANCE}

\section{Sun Min Lee et al • Evaluation of an Automated Stainer}

\section{재료 및 방법}

\section{1. 검체 및 장비}

성능 평가 중 정확도 평가를 위한 비교검사용 임상 검체는 2014년 10월부터 12월까지 양산부산대학교병원 진단검사의 학과에 그람염색 및 세균 배양 혹은 항산균 염색 및 배양검사 가 의뢰된 환자의 검체 중 잔여 검체를 대상으로 하였다. 검체 의 제외기준은 (1) 잔여 검체의 양이 적은 경우, (2) 접종 후 2 시간이 지난 검체, (3) 그람염색에서 객담 검체의 경우 저배율 $(\times 100)$ 에서 관찰하여 상피세포가 10 개 이상인 검체는 제외 하였다. 본 연구는 양산부산대학교병원 임상시험심사위원회 (institutional review board, IRB)의 승인을 얻어 시행되었다 (IRB No. 04-2014-021).

자동화 염색기 KS-S100을 평가하기 위해 비교용 장비 AT2000 (Dagatron, Goyang, Korea)을 사용하였고, AT2000 은 한 번에 20장까지 염색할 수 있는 반면, KS-S100은 40 장까지 염색할 수 있는 장점이 있었다. 염색용 시약은 $\mathrm{KS}^{-}$ $\mathrm{S} 100$ 제조사에서 생산한 그람염색액 및 항산성균 염색액 (Fluorochrome법) 제품을 사용하였다. 수기 그람염색에 사 용된 염색액은 YD Gram stain (YD Diagnostics, Yongin, Korea)으로 자동화 염색기와 다른 시약이 사용되었으며 항산 균 형광염색은 수기염색에서도 동일한 시약이 사용되었다. 본 평가기간에 사용한 염색시약의 제조번호는 각 검사별로 모두 동일한 것을 사용하였다.

\section{2. 방법}

1) 재현성

그람염색의 재현성 평가를 위해서 균 수와 염색성을 일정하 게 유지하기 위해 매일 계대 배양된 Staphylococcus aureus와 Escherichia coli 표준균주(순서대로 ATCC 25923와 ATCC 25922)를 McFarland 0.5 탁도의 부유액으로 균주별로 각 2장 씩 도말 슬라이드를 제작하였다. 평가기간 5 일간 오전과 오후 1 회씩, 총 10 회의 염색을 시행하여 가장 빈도가 높은 결과를 대표값으로 동일 등급 내 일치율과 대표값의 위 - 아래 한 등급 이내의 차이를 보이는, 한 등급 내 일치율을 구하여 평가하였 다. 항산균 형광염색의 재현성은 아래의 비교평가에서 시행된 2 회의 염색결과를 비교하여 일치하는지 확인하였다.

\section{2) 비교평가}

검사실에 그람염색과 세균 배양이 의뢰된 객담 및 기관지 세 척액 등 호흡기 검체의 잔여 검체로 각각 3장씩 도말표본을 제 작한 후 객담이나 기관흡인액의 경우 Murray와 Washington
변법을 이용하여 검체 질 평가에서 $[9,10]$ 부적절한 검체로 판 정되어 배양이 진행되지 않는 검체는 탈락시켰다. 그람염색상 세균이 검출되는 비정상 20 개와 검출되지 않는 정상 20 개를 선정하였다. 각각 세 가지 방법-수기염색법과 기존 사용 장 비인 AT-2000 (Dagatron)과 평가용 장비 KS-S100 (KS Co. Ltd.) - 으로 염색을 시행하였다.

항산균(Mycobacteria) 염색 평가를 위해 액체배양에서 각 각 음성과 양성 결과를 보인 배양액으로 6장씩 도말표본을 제 작한 후 항산균 형광염색을 위의 세 가지 방법으로 2 회씩 반복 시행하였다. 수기염색은 검사실 지침에 따라 시행하였고 2 명 의 연구자가 개별적으로 판독하여 고배율 $(\times 400)$ 관찰결과를 세계보건기구에서 제시하는 결과 보고지침에 따라 반정량 등 급으로 나누었다 1,2$]$. 두 판독결과가 불일치하는 경우 3 차 판 독을 시행하여 2 명이 일치한 결과를 채택하였다. 검사방법 간 비교를 수행한 검체는 모두 배양검사를 진행하였으므로 불일 치 결과해석 시 참고할 수 있었다(Table 1).

\section{3) 사용 편의성}

그람염색 슬라이드 1장, 10 장, 20장을 염색할 때 걸리는 시 간을 세 가지 방법별로 측정하여 비교하였다. 수기염색은 슬라 이드를 20장까지 꽂을 수 있는 틀을 사용하여 염색약이 담긴 항아리(jar)에 담가 염색을 하였는데, 슬라이드를 틀에 꽂고 빼는 과정에 걸리는 시간까지 합해서 측정하였다.

\section{4) 분석 및 통계}

그람염색은 관찰되는 균체의 성상과 상대적인 균의 수를 few, some, many로 표기하였고 항산균 형광염색은 염색별로 반정량 등급으로 나누었다[1,2]. 균종과 음성 및 양성의 정성

Table 1. Clinical specimens used to compare staining methods

\begin{tabular}{lcc}
\hline & \multicolumn{2}{c}{ No. of specimen } \\
\cline { 2 - 3 } Selected specimen types & Gram stain & $\begin{array}{c}\text { Acid-fast bacillus } \\
\text { fluorescence stain }\end{array}$ \\
\hline Sputum & 2 & 18 \\
Sputum, aspirated & 33 & 12 \\
Sputum, induced & 5 & 2 \\
Bronchial washing & & 2 \\
Body fluid & & 1 \\
Cerebrospinal fluid & & 1 \\
Tissue (lung) & & 3 \\
Urine & & 1 \\
Total & 40 & 40 \\
\hline
\end{tabular}




\section{Journal of LABORATORY MEDICINE and QUALITY ASSURANCE}

Sun Min Lee et al • Evaluation of an Automated Stainer

적 결과는 일치율을 구하였고, 도말표본에서 염색으로 관찰되 는 균의 수는 반정량 결과로 표기하였다. 2 회 반복 시행한 항 산균 형광염색의 균 수 결과는 평균값을 소수점 한자리의 등급 으로 환산하여 비교하였다. 균 수에 대한 반정량 및 등급결과 에 대하여 한 등급 이내의 차이를 보이는 비율인 한 등급 내 일 치율을 구하고, 수기염색과 KS-S100의 결과에 대한 Cohen' S weighted kappa $(\mathrm{Kw})$ 값을 구하였다. 자료정리와 통계분석 에 Microsoft Excel 2010 (Microsoft Corp., Redmond, WA, USA)과 Analyse-it for Microsoft Excel 4.90.4 (Analyse-it Software Ltd., Leeds, UK)을 이용하였다.

\section{결과}

\section{1. 재현성}

두 가지 표준 균주로 시행한 10 회의 그람염색 결과는 균종

Table 2. Non-concordant Gram staining results obtained using three different methods

\begin{tabular}{clll}
\hline \multirow{2}{*}{$\begin{array}{c}\text { Sample } \\
\text { no. }\end{array}$} & \multicolumn{3}{c}{$\begin{array}{c}\text { Results obtained using each staining method } \\
\text { (quantity of bacteria) }\end{array}$} \\
\cline { 2 - 4 } & KS-S100 & AT-2000F & Manual stain \\
\hline 59 & GPC (some) & GPC (few) & GPC (few) \\
& GNB (few) & GNB (some) & \\
74 & GPC (few) & GPC (few) & GPC (few) \\
& GNB (few) & & \\
\hline
\end{tabular}

Abbreviations: GPC, Gram positive cocci; GNB, Gram negative bacilli.
별 염색과 균 모양의 정성 결과 및 균 수 반정량 결과에서 모두 일치하였다. 항산균 형광염색에 사용된 40개 액체배양액의 검 체는 유도객담과 흡인객담을 포함한 객담(sputum)과 기관지 세척액(bronchial washing) 등 호흡기 검체 34개와 체액, 소 변, 조직 등의 배양액 5 개가 포함되었다. 세 가지 염색법마다 2회씩 반복 시행한 항산균 형광염색에서 음성과 양성이 불일 치하는 검체는 3 개(일치도 $37 / 40,92.5 \%$ )였다. 염색성 결과는 일치하는데 균 수만 차이가 나는 검체는 배양 음성인 배양액 1 개, 배양 양성인 배양액 9개였고, 염색방법별로는 수기염색 6 개, 기존장비 3 개, 평가장비 1 개이며 모두 한 등급 이내의 차 이였다.

\section{2. 비교평가}

그람염색 비교평가를 위하여 총 75 개의 호흡기 잔여 검체로 도말표본을 3장씩 제작하였고 객담 검체 질 평가결과 35 개가 탈락하여 기관지 세척액 6 개를 포함한 40 개의 검체가 선정되 었다. 세 가지 방법으로 시행한 그람염색에서 34 개의 객담 검 체는 모두 질 평가등급은 동일하게 관찰되었고, 세균이 관찰 되지 않는 정상 검체 20 개(진균양 세포 관찰된 2 개 포함) 결과 도 모두 일치하였다. 세균이 관찰되는 이상 검체 20 개 중 2 개 의 객담 검체에서 균의 성상이나 수가 수기염색과 일치하지 않 았으나(Table 2, 검체번호 59, 74), 균 수는 모두 한 등급 이내 의 차이였다. 총 40개에 대한 전체 일치율은 $95 \%$ (38/40)였 고, $\mathrm{Kw}$ 값은 0.94 (95\% 신뢰구간, 0.85-1.00)였다. 균종과 균 수가 일치하지 않는 2 개의 객담 검체의 배양결과는 우세한 균 종이 없었다.

항산균 배양액 40개를 선정해 세 가지 방법으로 항산균 형

Table 3. Comparison of the three acid-fast bacillus staining methods using culture-positive specimens $(\mathrm{N}=20)$

\begin{tabular}{|c|c|c|c|c|c|c|c|c|c|c|c|c|c|c|c|c|c|c|c|c|c|}
\hline & \multicolumn{20}{|c|}{ No. of sample } \\
\hline & & 11 & 12 & 13 & 14 & 15 & 16 & 17 & 18 & 19 & 20 & 31 & 32 & 33 & 34 & 35 & 36 & 37 & $38^{*}$ & 39 & 40 \\
\hline \multicolumn{2}{|l|}{ Specimen type } & S & B & S & S & S & $\mathrm{Si}$ & Sa & S & S & S & $\mathrm{T}$ & S & $\mathrm{T}$ & S & $\mathrm{Si}$ & $S$ & S & $S$ & S & B \\
\hline \multicolumn{2}{|c|}{ Differences of mean grade } & 0 & -1 & 0 & 0 & 0 & 0 & 0 & -1 & 0 & -1 & -1 & 0 & -1 & 0 & 0 & +0.5 & 0 & +1 & +0.5 & -1 \\
\hline \multirow[t]{2}{*}{ KS-S100 } & 1 st & $3+$ & $1+$ & $1+$ & $3+$ & $3+$ & $3+$ & $3+$ & $2+$ & $3+$ & $2+$ & $1+$ & $3+$ & $1+$ & $3+$ & $1+$ & $2+$ & $3+$ & $1+$ & $1+$ & $1+$ \\
\hline & 2nd & $3+$ & - & $1+$ & $3+$ & $3+$ & $3+$ & $3+$ & $2+$ & $3+$ & $1+$ & - & $3+$ & - & $3+$ & $1+$ & $2+$ & $3+$ & $1+$ & $1+$ & $1+$ \\
\hline \multirow[t]{2}{*}{ AT-2000 } & 1 st & $3+$ & $1+$ & $1+$ & $3+$ & $3+$ & $3+$ & $3+$ & $3+$ & $3+$ & $1+$ & $1+$ & $3+$ & $1+$ & $3+$ & $1+$ & $2+$ & $3+$ & $1+$ & $1+$ & $1+$ \\
\hline & $2 \mathrm{nd}$ & $3+$ & $1+$ & $1+$ & $3+$ & $3+$ & $3+$ & $3+$ & $3+$ & $3+$ & $2+$ & $1+$ & $3+$ & $1+$ & $3+$ & $1+$ & $2+$ & $3+$ & $2+$ & $1+$ & $1+$ \\
\hline \multirow[t]{2}{*}{ Manual stain } & 1 st & $3+$ & $2+$ & $1+$ & $3+$ & $3+$ & $3+$ & $3+$ & $3+$ & $3+$ & $2+$ & $2+$ & $3+$ & $1+$ & $3+$ & $1+$ & $1+$ & $3+$ & - & $2+$ & $2+$ \\
\hline & $2 \mathrm{nd}$ & $3+$ & $1+$ & $1+$ & $3+$ & $3+$ & $3+$ & $3+$ & $2+$ & $3+$ & $2+$ & $1+$ & $3+$ & $2+$ & $3+$ & $2+$ & $2+$ & $3+$ & - & $2+$ & $2+$ \\
\hline
\end{tabular}

The sample numbers in boldface indicate that the samples showed different results in duplicated staining with KS-S100. Abbreviations: S, sputum; B, bronchial washing; Si, induced sputum; Sa, aspirated sputum; T, tissue.

${ }^{\star}$ Negative culture result. 


\section{Journal of LABORATORY MEDICINE and QUALITY ASSURANCE}

\section{Sun Min Lee et al • Evaluation of an Automated Stainer}

광염색을 수행하였다. 자동화 장비 2종의 염색에서는 항산균 이 관찰되고 수기염색에서 관찰되지 않은 검체가 1 개 있어 전 체 결과 일치율은 97.5\% (39/40), $\mathrm{Kw}$ 값은 0.94 (95\% 신뢰구 간, 0.89-0.99)였다. 2회씩 반복한 세균 수에 대한 평균값을 비 교하면 양성 검체 20 개 중 7 개에서 방법 간 차이를 보였으나 모두 한 등급 이내였다(Table 3).

\section{3. 사용편의성}

수기염색은 20장까지 염색시간은 6분 12 초(372초)로 동일 하지만 슬라이드 수에 따라 틀에 꽂고 빼는 시간이 걸려 10장 을 염색할 때 7분 2초(1장당 42.2초), 20장은 8분 44초(1장당 26.2 초)가 소요되었다. 자동화 장비를 사용하여 1장 염색할 때 AT-2000는 9분 7초, KS-S100는 10분 20초로 수기염색 대 비 1.5-1.8배의 염색시간이 걸리지만 10장을 염색할 때는 AT2000 12분 36초, KS-S100 12분 32초로 수기염색 대비 1.9-2 배의 시간이 걸려 1 장당 소요시간은 많은 수의 슬라이드를 염 색할수록 줄어들었다. 평가용 장비 KS-S100은 10장을 염색할 때는 12 분 32 초로 기존장비 AT-2000의 12 분 36초와 유사했 으나 20장을 염색할 때는 14 분 45 초로 19 분 27 초보다 짧았다.

\section{고찰}

현대 의료에서는 임상검사실에 대해 높은 재현성과 정확도 가 요구되고 있으며 그것은 수기로 시행하는 검사가 많은 미 생물검사 분야에서도 마찬가지이다. 미생물 도말표본의 염색 도 수기로 시행하는 대표적 검사 중 하나이며 적절히 수행하기 위해 검사자 숙련과정이 필요하다. 일정 기간의 숙련기간이 필 요한 수기검사를 장비를 사용해 시행하는 경우 도입 시 재현성 과 정확도 평가는 필수적이라 할 수 있다. 최근 사용되고 있는 자동화 염색장비는 검사자의 안전상의 문제에 대한 대안을 제 시할 수 있을 뿐 아니라 검사실의 업무흐름을 개선할 수 있다 [5].

평가장비인 KS-S100는 그람염색 재현성 평가에서는 일치 된 결과를 보였으나, 항산균 형광염색에서 2 회 반복 결과가 다 른 경우가 항산균 양성 20 개 중 3 개에서 발생하였다. 해당 3 개(Table 3 , 검체번호 $12,31,33$ )는 항산균 배양을 시행한 검 체가 기관지 세척액 1 개, 조직 2 개였고 적은 수의 균이 검출되 었지만, 비교를 위해 시행한 기존 자동화 장비 AT-2000의 염 색결과는 두 번 모두 $1+$ 로 나왔고 양성으로 보고된 도말표본 일부에서 초록색 나선균이 발견되었으므로 평가장비의 염색 에 문제가 있을 수 있다고 판단하였다. 본 연구를 지원한 국산 의료기기 평가사업의 과정 중 제조사에 발견된 문제점을 알리
고 개선하는 과정이 있어 제조사와 의논하여 자동염색 프로그 램에서 auramine-rhodamin 형광액을 얹은 후 대기하는 시간 을 1 분 더 늘리자 초록색 형광을 뜬 나선균은 발견되지 않았다 (자료 미제시). 이후 같은 방법으로 재평가를 시행하지는 못했 으나 이와 같은 조치가 자동화 장비 성능 평가결과에 대한 검 사실의 조치사항의 예가 될 수 있다. 도말표본 간의 두께 차이 가 없는 배양액 도말임에도 동일인이 수행한 수기염색에서 장 비 사용 시보다 더 많은 6 개 검체에서 한 등급 이내지만 균 수 의 차이를 보인 결과는 미생물 염색검사에서 장비 도입 필요성 의 근거가 될 수 있다.

세 가지 방법 비교평가에서는 그람염색은 2 개의 양성 검체 에서 보고 균종의 차이를 보였는데, 두 가지 균종을 보고한 평 가장비 $\mathrm{KS}-\mathrm{S} 100$ 이 배양결과에 더 부합하는 결과를 보였다. 이는 같은 검체라 하더라도 객담 등 호흡기 검체의 특성상 균 종과 분포의 차이를 보일 수 있고, 국내에서 시행되는 신빙도 조사 정답률을 고려하면[8] 일치도 $92.5 \%$ 는 임상적으로 사용 할 수 있는 수준으로 판단된다. 항산균 액체 배양기에서 양성 으로 검출하여 비정상 검체로 선정되었는데 최종적으로 오염 으로 판정된 검체 1 개(Table 3 , 검체번호 38 ) 외에는 2 회 반복 결과의 평균값이 수기염색 결과와 일치하였다. 항산균 양성 검 체 7 개에서 균 수 등급이 차이가 났지만 모두 한 등급 이내로 일치하므로 검사실에서 사용할 수 있는 수준이었다.

자동화 장비를 사용한 염색은 수기염색 대비 1.5-2배의 염 색시간이 걸려 적은 수의 도말표본을 신속히 염색해야 할 때는 필요성이 적다. 수기염색은 검사자가 6 분 12 초의 염색시간 동 안 1-2분 간격으로 작업을 해야 하지만 자동화 염색기를 사용 하면 장비가 가동되는 약 10-20분 동안 다른 작업을 할 수 있 는 시간(walkaway time)이 확보된다. 한번에 염색할 표본 양 이 많은 검사실에선 1 회의 가동시간이 짧은 것이 회전율을 높 일 수 있는데 평가용 장비는 기존 장비보다 수세시간이 짧아 20 장 염색 시 1 장당 소요시간이 $21.3 \%$ 짧았다. 자동염색기 도 입 시에는 총 염색량뿐 아니라 한번에 처리하려는 슬라이드 수 를 고려해야 하겠다.

본 연구에서 평가한 염색은 오랜 기간 수기로 시행되어 왔으 나 최근에는 자동화 염색기를 사용하는 검사이다. 그람염색은 폐렴이나 패혈증과 같은 세균성 감염에 대한 진단 초기에 중요 한 역할을 하는 검사이며, 항산균 도말검사는 결핵이 의심되는 환자에서 가능한 빨리 시행하여 진단하는 것이 전염성이 높은 환자를 신속히 관리할 수 있다[2]. 검사량이 많은 대형 병원의 검사실의 업무를 효율화하는 것 이외에도 숙련된 기술이 없거 나 검사자 안전이 우려되는 경우에 자동화 염색장비 사용을 고 려할 수 있다. 수기염색에서 시약에 의한 오염이나 시약 교체 


\section{Journal of LABORATORY MEDICINE and QUALITY ASSURANCE}

Sun Min Lee et al • Evaluation of an Automated Stainer

후 탈색이 되는 현상이 발생할 수 있으나 부족한 시약을 수시 로 보충하는 장비는 그런 영향은 거의 없었다. 검체량이 적으 면 수기염색보다 검사소요시간이 더 길어질 수 있다. 또한 염 색성의 문제는 자동염색기를 사용하더라도 완전히 피할 수는 없기 때문에〔3] 장비 도입 시 객관적인 평가를 시행할 필요가 있다. 재현성이 높더라도 표준균주로 시행하는 내부정도관리 가 양호하더라도 임상 양성 검체로 판독자 변이를 제어하여 객 관적 평가를 시행할 필요가 있다. 이전에 자동염색기를 평가한 논문은 항산균 형광염색에 대한 평가로 적은 균 수를 가진 검 체에서 불일치한 결과나 일치율을 유사하였다[5-7]. 본 연구 에서는 미생물학적 검사를 위해 사용되는 두 가지 염색검사에 대한 자동염색기의 성능 평가를 실제 임상검사실에 접수되는 호흡기 검체로 시행하였다. 균이 발견되는 이상 검체를 절반 에 해당하는 20 개만 선정하여 염색 양성 검체 수가 통계적 분 석을 하기에 부족했고, 평가용 장비에서 염색성에 차이를 보여 염색액 반응시간을 조정하였으나 조정 후 재평가를 시행하지 는 못했다. 또한 그람염색에 대해서는 두 가지 표준균주로 재 현성을 평가하였으나 항산균에 대해서는 그러지 못했다. 추가 적 평가를 시행한다면 이보다 더 많은 수의 비정상 결과를 보 이는 임상 검체로 평가를 시행하는 것이 통계적 타당성이 높일 수 있을 것으로 생각된다.

자동화 장비를 이용한 염색검사는 임상적으로 사용할 수 있 는 수준의 성능으로 판단된다. 염색을 시행하는 도말 검체의 수에 따라서 사용편의성이 다를 수 있고, 일부 양성 검체에서 차이를 보일 수 있으므로 임상 미생물검사실에서 수기염색을 자동화 장비로 대체할 때에는 객관적인 성능 평가가 반드시 필 요하다.

\section{감사의 글}

본 연구는 양산부산대학교병원 진단검사의학과 미생물감염 검사실의 도움을 받아 한국보건산업진흥원 국산의료기기 신 제품 사용자(의료기관) 테스트 지원사업에 (주)케이에스와 함 께 참여하여 지원받은 연구비로 수행되었다.

\section{REFERENCES}

1. Hall GS, Woods GL. Medical bacteriology. In: McPherson RA, Pincus MR, editors. Henry's clinical diagnosis and management by laboratory methods. 23rd ed. St. Louis (MO): Elsevier, 2017: 1114-52.

2. Korea Society Laboratory Medicine. Mycobacteria, Nocardia, and other aerobic actinomycetes. In: Korea Society Laboratory Medicine, editor. Laboratory medicine. 5th ed. Seoul: E-public, 2014:631-7.

3. Joint Committee for the Revision of Korean Guidelines for Tuberculosis. Korean guidelines for tuberculosis. 3rd ed. Cheongju: Korea Centers for Diseases Control and Prevention, 2017.

4. Woods GL. Mycobacteria. In: McPherson RA, Pincus MR, editors. Henry's clinical diagnosis and management by laboratory methods. 23rd ed. St. Louis (MO): Elsevier, 2017:1187-97.

5. Kim SY, Kim YJ, Hwang SH, Kim HH, Lee EY, Chang CL. Evaluation of an acid-fast bacilli autostainer for concentrated sputum smears. Int J Tuberc Lung Dis 2008;12:39-43.

6. Kim SY, Yang EK, Kim YJ, Lee SM, Lee EY, Park YK, et al. Evaluation of automatic acid-fast bacilli stainer AT2000F. Korean J Clin Microbiol 2006;9:115-8.

7. Kim SC, Kang SI, Kim DW, Kim SC, Cho SN, Hwang $\mathrm{JH}$, et al. Development and evaluation of an automated stainer for acid-fast bacilli. Med Eng Phys 2003;25:341-7.

8. Ko YJ, Kim MN, Kim EC, Shin JH, Lee NY, Kim S, et al. Annual report on external quality assessment scheme for clinical microbiology in Korea (2014). J Lab Med Qual Assur 2015;37:153-78.

9. Korea Society Laboratory Medicine. Diagnosis of bacterial infections by organ system. In: Korea Society Laboratory Medicine, editor. Laboratory medicine. 5th ed. Seoul: E-public, 2014:544-6.

10. Beavis KG, Charnot-Katsikas A. Specimen collection and handling for diagnosis of infectious disease. In: McPherson RA, Pincus MR, editors. Henry's clinical diagnosis and management by laboratory methods. 23rd ed. St. Louis (MO): Elsevier, 2017:1289-93. 


\section{자동 미생물 염색기 KS-S100의 성능 평가} 이선민 • 이현지・장철훈

양산부산대학교병원 진단검사의학과

배경: 그람염색과 항산균(acid-fast bacilli, AFB) 도말검사는 수기로 시행하여 검사자의 숙련도가 중 요하나 자동염색기 사용에 대하여 객관적인 성능 평가자료가 부족하다. 이에 본 연구자들은 최근에 개발된 자동염색기 KS-S100 (KS Co. Ltd., Korea)를 사용한 그람염색과 AFB 형광염색의 재현성과 정확성, 사용편의성을 평가하였다.

방법: 그람염색에 대한 재현성 평가는 그람 양성 및 음성 표준균주 부유액 도말표본으로 5일간 총 10 회 시행하였고 AFB 형광염색은 2회 반복 시행결과를 비교하였다. 그람염색 및 AFB 형광염색 비

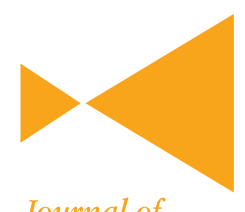

Journal of

LABORATORY MEDICINE and

QUALITY ASSURANCE 교평가를 위해 하부 호흡기 검체 혹은 AFB 액체배양액으로 각각 3장과 6장씩 도말표본을 제작한 후 정상과 비정상 검체를 각각 20개씩 선정하여 기존 장비 AT-2000 (Dagatron, Korea)와 평가장비 $\mathrm{KS}-\mathrm{S} 100$, 그리고 수기법으로 염색을 시행하였다. 복수의 판독자가 암맹 경검하였고 각각 1장, 10 장, 20장을 염색하면서 총 소요시간을 측정하였다.

결과: 그람염색 10 회 반복결과는 모두 일치하였고, AFB 형광염색은 40 개 검체 중 반복 염색결과 가 불일치하는 검체가 3 개 있었다. 세 염색법의 비교결과 정상 검체 결과는 모두 일치하였으나, 비 정상 결과를 보이는 그람염색 2 개, AFB 형광염색 1 개의 검체에서 결과가 불일치하여 전체 결과 일 치율은 각각 $95 \%$ 와 $97.5 \%$ 였다. 균 수에 차이를 보이는 경우도 한 등급 이내였다. 1장 염색 시에는 수기염색이 빠르고 20장을 염색할 때는 KS-S1000 이유리했다.

결론: KS-S100 장비를 사용한 그람염색 및 AFB 형광염색은 재현성이 있고 수기 및 기존 장비와 비교하여 유효한 결과를 보여 임상검사실에서 사용할 수 있는 성능을 가졌다고 판단된다. 임상 미 생물 염색에 자동화 장비를 사용하는 경우에도 객관적인 성능 평가가 수행되어야 할 것이다.

(J Lab Med Qual Assur 2017;39:162-167)

교신저자: 장철훈

우)50612 양산시 물금읍 금오로 20 , 양산부산대학교병원 진단검사의학과

Tel: 055)360-1877, Fax: 055)360-1880, E-mail: cchl@pusan.ac.kr 